\title{
A Woodland Period Goose Creek Plain, var. unspecified Sherd from 41WM1382 in Central Texas
}

Timothy K. Perttula

Follow this and additional works at: https://scholarworks.sfasu.edu/ita

Part of the American Material Culture Commons, Archaeological Anthropology Commons, Environmental Studies Commons, Other American Studies Commons, Other Arts and Humanities Commons, Other History of Art, Architecture, and Archaeology Commons, and the United States History Commons

Tell us how this article helped you.

This Article is brought to you for free and open access by the Center for Regional Heritage Research at SFA ScholarWorks. It has been accepted for inclusion in Index of Texas Archaeology: Open Access Gray Literature from the Lone Star State by an authorized editor of SFA ScholarWorks. For more information, please contact cdsscholarworks@sfasu.edu. 
A Woodland Period Goose Creek Plain, var. unspecified Sherd from 41WM1382 in Central Texas

\section{Creative Commons License}

(c) (i) (8)

This work is licensed under a Creative Commons Attribution-NonCommercial 4.0 International License 


\title{
A Woodland Period Goose Creek Plain, var. unspecified Sherd from $41 \mathrm{WM} 1382$ in Central Texas
}

\author{
Timothy K. Perttula
}

41WM1382 is in the Brushy Creek valley in Williamson County, Texas, near the community of Normans Crossing. Brushy Creek is an eastward-flowing tributary of the San Gabriel River in the Blackland Prairie natural region in the Brazos River basin. The site's principal archaeological deposits date to the Late Archaic period (between ca. 4000-1200 years B.P.), but one ca. A.D. 900-1200 Kiam Incised sherd has been found here (Perttula and Mikulencak 2018).

Recent digging at 41WM1382 uncovered a plain non-tempered sandy paste rim sherd (Figure 1) from a Goose Creek Plain, var. unspecified vessel, probably a jar. The rim sherd is $7.1 \mathrm{~mm}$ thick, with a rounded lip and a direct profile, and neither the interior or exterior surfaces have been smoothed or burnished. The vessel had been fired and cooled in a reducing or low oxygen environment, leaving the vessel surfaces dark gray in color.

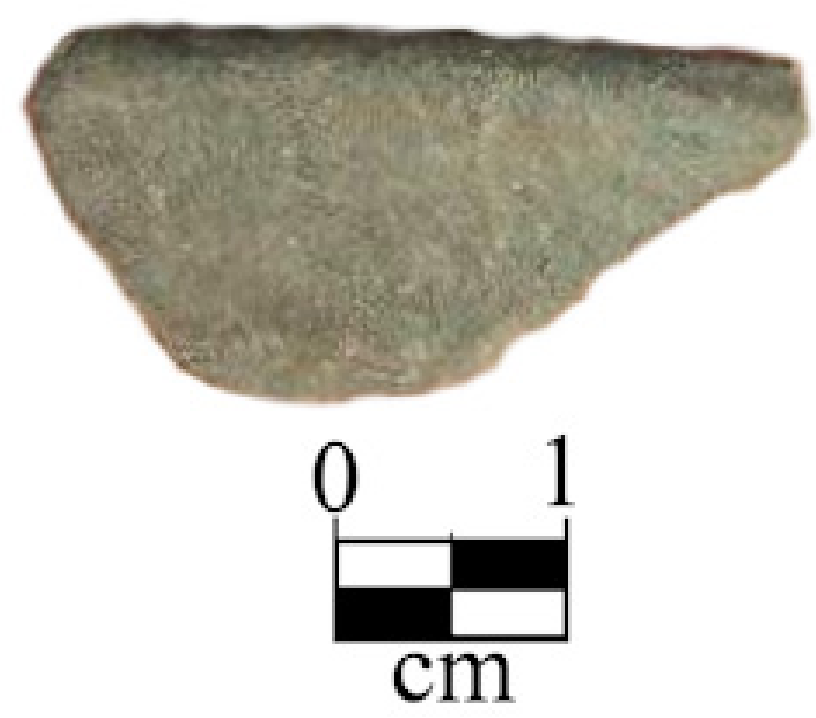

Figure 1. The Goose Creek Plain, var. unspecified rim sherd from 41WM1382.

Based on a recent and broad study of certain kinds of aboriginal ceramic wares found in Central Texas sites (Perttula 2018), a total of thirteen sites are known in the region that have small amounts of plain sandy paste Goose Creek Plain, var. unspecified pottery. This ceramic ware was made and used by Mossy Grove Culture Woodland period peoples between ca. 500 B.C.-A.D. 800 (see Aten and Bollich 2002; Story 1990; Ellis 2013). In Central Texas, these sites are concentrated in the Brazos River basin in Hill, McLennan, and Williamson counties in the Blackland Prairie (Figure 2). 


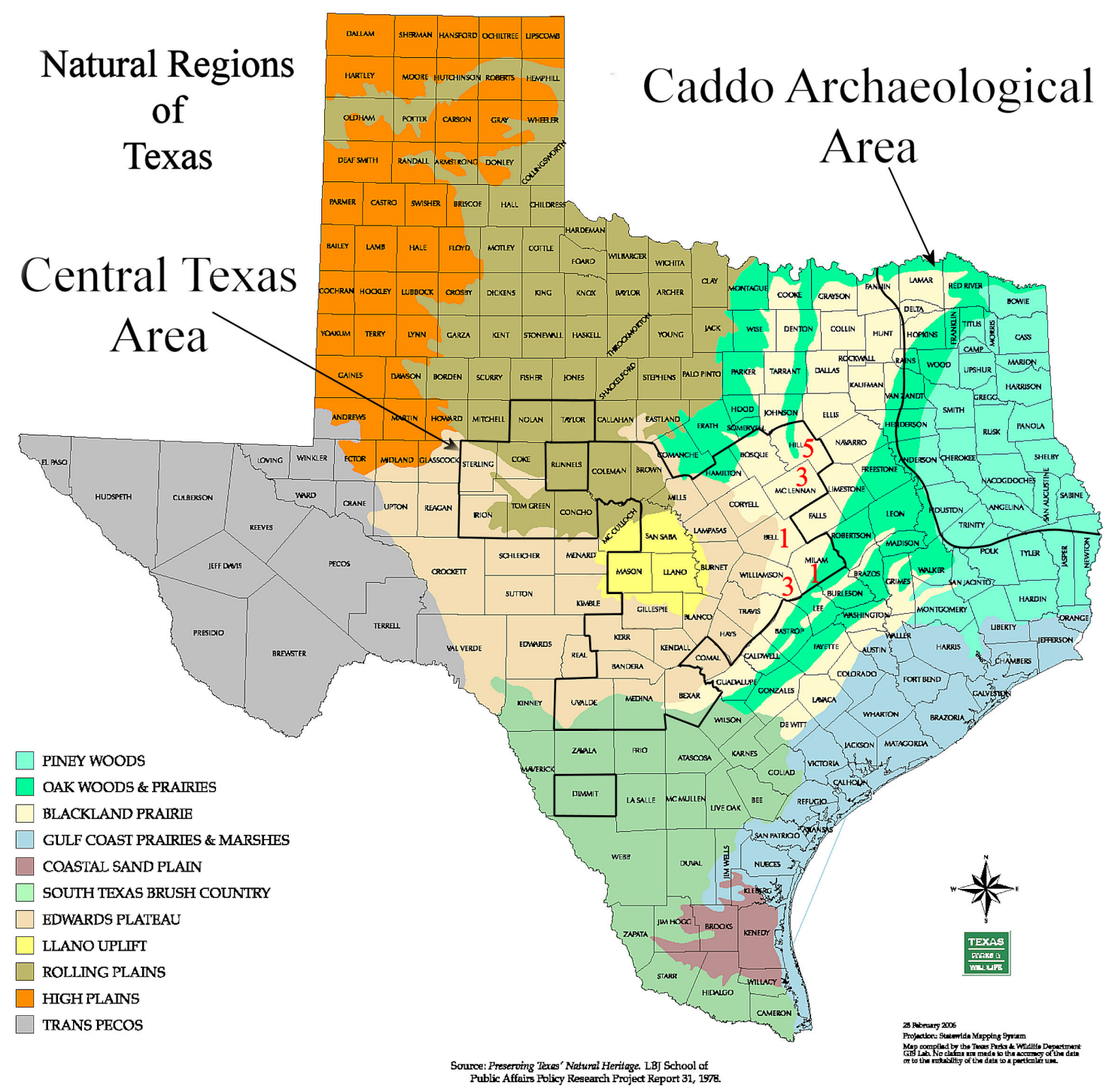

Figure 2. Distribution of sites by number per county with Mossy Grove Culture Goose Creek Plain, var. unspecified ceramics in Central Texas sites.

The presence of this distinctive ceramic type in the Central Texas region, although uncommon, indicates that there were occasional contacts and the exchange of materials and information between Central Texas hunter-gatherers and Mossy Grove peoples. These people lived to the east and southeast of Central Texas in the Post Oak Savannah and Pineywoods, as well as probably the Prairies and Marshes of the upper Texas Gulf Coast (see Perttula 2018:Figure 88).

\section{Acknowledgments}

I thank Ken Mikulencak for providing me the opportunity to examine the Goose Creek Plain, var. unspecified sherd from 41WM1382. Lance Trask prepared the figures for this article; the original version of Figure 1 was provided by Ken. 


\section{References Cited}

Aten, L. E. and C. N. Bollich

2002 Late Holocene Settlement in the Taylor Bayou Drainage Basin: Test Excavations at the Gaulding Site (41JF27), Jefferson County, Texas. Studies in Archeology 40, Texas Archeological Research Laboratory, The University of Texas at Austin, and Special Publication No. 4, Texas Archeological Society, San Antonio.

Ellis, L. W.

2013 Woodland Ceramics in East Texas and a Case Study of Mill Creek Culture Ceramics. Bulletin of the Texas Archeological Society 84:137-180.

Perttula, T. K.

2018 The Occurrence of East Texas Caddo Ceramic Vessel Sherds in Central Texas Archaeological Region Sites, ca. A.D. 900 to the late $18^{\text {th }}$ Century. Special Publication No. 47. Friends of Northeast Texas Archaeology, Austin and Pittsburg.

Perttula, T. K. and K. Mikulencak

2018 Caddo Ceramic Vessel Sherds from 41WM763 and 41WM1382 in the Brushy Creek Valley, Williamson County, Texas. La Tierra, in press.

Story, D. A.

1990 Cultural History of the Native Americans. In The Archeology and Bioarcheology of the Gulf Coastal Plain, by D. A. Story, J. A. Guy, B. A. Burnett, M. D. Freeman, J. C. Rose, D. G. Steele, B. W. Olive, and K. J. Reinhard, pp. 163-366. Research Series No. 38. Arkansas Archeological Survey, Fayetteville. 